\title{
THE METHOD OF ESTIMATING DEPENDABILITY OF SUPPLY CHAIN ELEMENTS ON THE BASE OF TECHNICAL AND ORGANIZATIONAL REDUNDANCY OF PROCESS
}

\author{
METODA SZACOWANIA NIEZAWODNOŚCI ELEMENTÓW \\ ŁAŃCUCHA DOSTAW NA PODSTAWIE CHARAKTERYSTYK \\ NADMIAROWOŚCITECHNICZNEJ I ORGANIZACYJNEJ PROCESU
}

\begin{abstract}
The quality of supply chain operation depends on quality of its particular elements, including warehouses. The paper presents an attempt to describe the quality of warehouse operation in terms of dependability. Authors discussed issues related to assessing warehouse operation, quality problems and solutions to increase the quality of work. The technical and organizational redundancy was proposed as a primary factor increasing dependability of warehous operation in supply chain and thereby improving the quality of services. Authors discussed dependability of supply chain and warehouses and have proposed an approach to determination of dependability of warehouse facility based on technological and organisational redundancy related to material flow pile-ups. The approach was founded on OTIFEF index as a base for dependability estimation. Construction of that index basing on probabilities of correct realization of different aspects of logistics service was proposed. An important element of the approach presented in the paper is proposal of technical and organisational indicators defining different aspects of redundancy in aspect of dependability. The example of redundancy assessment in function of technical and organisational methods of increasing warehouse efficiency has been provided.
\end{abstract}

Keywords: warehouse dependability, technological redundancy, organizational redundancy, material flow pileup, supply chain

\begin{abstract}
Jakość pracy łańcucha dostaw jest wynikiem jakości pracy jego elementów, w tym magazynów. W artykule przedstawiono próbę ujęcia zagadnień jakościowych pracy magazynu w kategoriach niezawodnościowych. Omówiono zagadnienia oceny pracy magazynów, źródła problemów jakościowych i stosowane rozwiązania zwiększające jakość pracy. Wskazano nadmiarowość techniczna i organizacyjna jako podstawowy środek zwiększania niezawodności realizacji zadań przez magazyny w łańcuchu dostaw i tym samym poprawę jakości świadczonych ustug. Autorzy omówili zagadnienia niezawodności łańcucha dostaw i magazynów jako ich podstawowych elementów i zaproponowali podejście do określania niezawodności magazynu oparte o nadmiarowość technologiczna $i$ organizacyjna ustalana $w$ oparciu o przewidywane spiętrzenia przepływu materiałów. Do tego celu wykorzystano miernik OTIFEF jako podstawe szacowania niezawodności. Zaproponowano konstrukcje tego miernika w oparciu o prawdopodobieństwa poprawnej realizacji różnych aspektów usług logistycznych. Ważnym elementem podejścia proponowanego wartykule jest propozycja technicznych i organizacyjnych wskaźników określajacych różne aspekty nadmiarowości w funkcji niezawodności magazynu. Przedstawiono przykład szacowania nadmiarowości z wykorzystaniem technicznych i organizacyjnych metod zwiększania efektywności.
\end{abstract}

Slowa kluczowe: niezawodność magazynu, nadmiarowość technologiczna, nadmiarowość organizacyjna, spiętrzenia w przepływie materiałów, tańcuch dostaw.

\section{Introduction}

A key feature of any technical system, including logistics system, is work quality influencing user satisfaction. The quality of logistics services may be considered in relation to the time of delivery, security, dependability etc. in relation to costs $[9,11])$. The quality of a logistic system services can be considered using dependability issues, but applying classic measures of dependability is impeded for logistics systems due to their complexity and necessary process-based approach to research.

Supply chain is a specific case of a logistics system. According to the serial structure of supply chain its quality, especially in technical matters, depends on quality of individual components [5]. These components - facilities and subsystems - perform processes of material transport, buffering and transformation.

Transport subsystems in supply chain determine efficiency and duration of material movement. They can be also a source of delays, damages and loss of materials. Warehouses buffer and transform materials as well as hold and deploy stock. Thus, warehouses determine accessibility of materials for clients and time of response for order. They are also places where the smallest possible pieces of materials in supply chain are touched (handled and transformed), so warehouses are potential sources of qualitative and quantitative errors. Warehouse processes are affected by the risk of damage to materials. Storage

$\left(^{*}\right)$ Tekst artykułu w polskiej wersji językowej dostępny w elektronicznym wydaniu kwartalnika na stronie www.ein.org.pl 
process lowers value of materials and generates costs of maintaining inventory. These negative factors must be investigated and eliminated in order to improve the quality of services provided throughout the supply chain.

Therefore, warehousing seems to be important for the quality of services in the supply chain due to the broad spectrum of possible adverse events and errors caused by warehouses and identified by final customer. In case of transport subsystem shortcomings of performance can be quickly counteracted by using additional means of transport. In case of warehouses storage and handling capacity often cannot be achieved through simple organizational methods. In that case performance affects the timeliness and this, in turn, determines the quality.

Irregularities in logistics services result from errors of supply and distribution planning (not considered in this paper), technical deficiencies and inadequate organization. Hence we come up to the question as to the way that warehouses should operate, and in particular which technical means should they be fitted with to allow the undisturbed progress of warehousing processes in accordance with customer expectation? One of the elementary methods of enhancing dependability of systems is redundancy. Redundancy is understood as the application of a larger number of elements as compared to what is necessary or generally accepted. Those elements may comprise additional devices, people, space or information to be assured in case of damage or lack of efficiency of a system.

In the paper the authors have proposed a certain approach to warehouses services quality included in dependability categories. On that base they have discussed possibility of warehouse dependability improvement based on technological and organisational redundancy. In this context they have presented the research oriented at the dependability of logistic systems, particularly taking into account technical solutions in implementation of warehouse processes and supply chains. An important element of the presented approach is model presented in 5. point to determine selected characteristics of warehouse dependability in relation to material flow pile-ups. Additionally, authors propose factors of technical and organisational redundancy included into dependability structure of the warehouse.

\section{Warehouse and supply chain dependability issues}

In accordance with standards $\mathrm{PN}-82 / \mathrm{N}-04001$ and $\mathrm{PN}-93 / \mathrm{N}-$ 50191 , dependability of a system (technical facility) is generally defined as a set of features that describe the readiness of the facility as well as reliability, maintainability and assuring maintenance support that affect it. According to Nowakowski $[19,20]$, when defining the dependability of a logistic system, the following should be taken into account:

- dependability of this system is understood only as a measure of task implementation over time, which may be compared to the reliability of technical system,

- no equivalent of maintainability or reliability of technical system has been formulated for logistics systems,

- all measures have the nature of coefficients, as a rule structure indicators; no other characteristics have been made use of, even though processes subject to assessment may also be random ones.

In other place Nowakowski [19] defines the dependability of logistics system through its availability. In a classic form function of availability of recoverable object describes the probability of its proper functioning in a specific moment of time [34]. Warehouse availability describes its ability of timely undertaking and successful performance of tasks arising from supply chain. It depend on the availability of resources, i.e. people, devices and means of internal transport, available time, control and measuring devices and buffering capability ([16], as per Logistics Management Institute). Dependability of the warehouse is a function of availability to handle supplies (unloading, receiving and put- away in the reserve area) as well as shipment (retrieving, replenishment, picking, sorting, consolidation, loading). The level of logistic services executed by the warehouse may be considered to be sufficient, and consequently the availability of the warehouse satisfactory, if at the fixed level of costs:

- number and structure of qualitative errors are at an acceptable level,

- services are provided on time, in accordance with the contract concluded with the customer,

- acceleration or cancellation of customer orders is possible in specific conditions,

- the facility is capable of handling pile-ups in material flows on time, without an adverse consequence for the remaining participants of the supply chain,

- the warehouse may, within preset limits, respond to changes in the goods structure or change in the structure in customer orders without increasing the number of occurring errors and maintaining the required timeliness.

Dependability is no easily measurable factor considered in designing logistic systems $[10,18]$. In supply networks the issues of dependability are most frequently limited to the supply process. In this respect Nowakowski $[19,20]$ indicates that dependability in the operation of supply chains may indicate: timely task execution, complete implementation of an order and receipt or release of undamaged goods. A measure of functioning dependability of the system are disturbances and reduction of its performance $[10,18]$. In this context the analysis comprises the flexibility of the system, i.e. the ability to adapt and to deploy changes in the operating scope and possibilities of increasing the operation area.

Numerous studies related to problems of dependability in supply chains $[1-3,8]$, take into account issues related to reducing system efficiency and changes in the loading of transport routes within the network [24, 27]. Sohn and Choi [28] analyse issues related to managing a supply chain in relation to the reliability of subsequent stages - logistic processes, including warehouse processes. They emphasise the need to include reliability issues already at the stage of designing. Bukowski and Feliks [6] search for a unified concept to evaluate dependability of complex supply chain. Baghalian et al. [1] present a mathematical model of the forming of broad assortment supply chains, which takes into account uncertainty on the demand and supply side. This uncertainty translates into material flow pile-ups on warehouse entrance and exit.

Quite interesting research of the impact exerted by the seasonality on the dependability level in transport services of spare parts was presented by Juściński and Piekarski [12]. The authors have set out the value of seasonal indices for the given period and analysed the distribution of their changes in the aspect of anticipated demand for spare parts for machines.

Issues of strategic management of the supply chain and planning of infallible warehouses functioning in regular conditions, as well as in conditions of unforeseen disturbances, have been subject of analyses performed by numerous authors [21, 25]. Peng et al. [21] presented a model for minimising the cost of logistic tasks implementation with concurrent minimising of the risk that the performance of those tasks would be discontinued. Neo et al. [15] analyse the impact of lack of warehouse technical efficiency on selected criteria of quality assessment of its operation. Furthermore, they point to the accuracy of information order-picking processes and timely execution of deliveries as crucial quality indicators.

Rizzi and Zamboni [23] regard logistic processes in manual warehouse of finished goods using ERP system to improve the productivity of the warehouse. The authors have pointed to the fact that the deployment of an integrated IT system is not guarantee for rationalising warehouse operation. 
Werbińska-Wojciechowska [33] presents a model of maintaining technical systems on the example of logistic systems using the concept of time delays. Author points to the effectiveness of the devised model on the example of internal transport devices. In other work Werbińska-Wojciechowska [32] discusses the integration of the system executing the task with the supportive system like the logistics system.

Quality of services has considerable importance as it comes to dependability and is rather significantly highlighted by certain authors $[26,29,30]$. The authors perceive quality as a level at which customer requirements are met by services providers. For example in the study [26] as the Author describes the multidimensional nature of the quality, he states that the quality assessment should concern the dependability of operation of transport means and human resources, IT resources, infrastructure, technical equipping, and rules of system organisation. On the other hand, Chung and others [7] take up the issue of work quality and the dependability of warehouses in relation to the specialisation of the supply chain and the consequent possibility of re-using package resources. The authors propose the use of genetic algorithms as a tool for effective planning of dependability.

The crucial feature of dependability of supply chain and warehouse is the determination of the whole system faultless probability. This is difficult for complex structures like logistic systems, in the case of which classical damage causing lack of fitness of use is not applicable. Often warehouse processes are significant source of errors. In this context the appropriate number and selection of technical means has a particular significance. For this reason, it is necessary to specify selected technological and organisational measures for the selection of technical means to secure the implementation of warehouse processes. The selection must take into consideration the diversity of orders obtained from clients, and the irregularity of supplies.

On the basis of the performed review of literature an assumption may be made that there is a research gap on the impact of redundancy on dependability and the operating cost of the warehouse system, especially as regards technical solutions that may be allowed for use during designing of warehouse systems - when the precise progress of processes described by the history of order implementation and supply handling is not available.

\section{Technological and organizational redundancy versus warehouse dependability}

Review of literature and observations made in practice indicate that the lack of dependability of the warehouse process is connected with the following:

- human errors that generate repair tasks (additional labour, cost and delay), cause inconsistency of stock and reduce the quality of services in the supply chain,

- unforeseen pile-ups in the flow of materials causing lack of handling of current supplies and shipments,

- seasonal and long-term changes in the structure of supplies and shipments, which cause an insufficiency in performance and lack of technological suitability for the tasks,

- unreliability of mechanical equipment and facilities - especially the key elements of storage systems, such as AS/RS,

- warehouse and enterprise information systems errors (mismatching), poor quality planning.

Errors in warehouse process may be of two types: of internal or external nature in relation to the system. The first type of errors most frequently are an effect of human errors, an objective shortage of efficiency (productivity), mismatching of the technology and the tasks, shortage of buffering capacity and storage, and random events. External ones, from the viewpoint of the warehouse, arise exclusively from random causes connected with changes in changes to the supply structure. The nature and scope of those changes is not reviewed at the warehouse level but is subject of planning of the supply chain (Fig. 1).

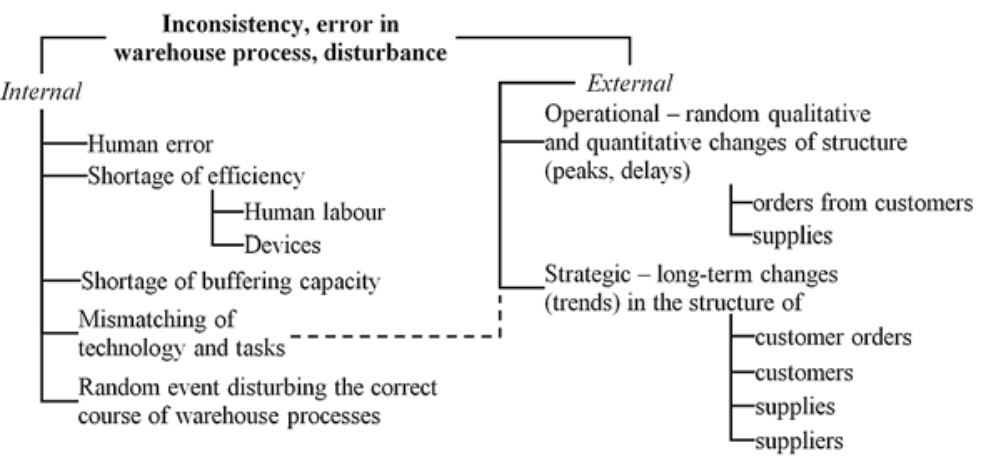

ig. 1. Classification of sources of errors and hindrances that limit the warehouse dependability. Source: [14]

The conducted research $[4,16,17]$ clearly points to a necessity of carrying out an analysis of a sample of historical data with view to dependability to set out measurable indicators related to the number and types of possible errors. On that base warehouse technologies and methods of work organisation are selected to reduce the number or change the structure of errors in the implementation of warehouse processes.

Problems in implementation of warehouse processes, such as the lack of punctuality, may be a result of the absence of handling potential or lack of suitability of the potential to random pile-ups in material flows [31]. A negative influence of random peaks in daily material flows on its uninterrupted operation is flattened by daily pile-up coefficients expressing technological redundancy allowed for in the designing stage. The coefficients increase average daily volumes to set reliable (nominal) material volumes covering the majority of daily flow peaks (section 5). The application of pile-up coefficients that describe processes of supplies and shipments enables taking into account the efficiency overcapacity in planning of warehouse processes, and consequently enhancing the dependability of the facility.

The pile-up coefficients do not take into account extraordinary situations or long-term trends in the supply chain that arise from the seasonal change in the structure of flows and supplies, and long-term changes on the market. The basic way of coping with them is the periodical change in work organisation and adaptation of efficiency. Long-term changes tend to reduce the availability to providing services and require the adoption of flexible solutions offering the given possibility of adaptation which, in turn, are connected with the technological universality and with the anticipated redundancy (installed in practice and potential one).

Typical methods of eliminating the above mentioned issues are as follows:

- technological redundancy enhancing the dependability of the system, including

- increasing the capacity of functional areas (specially storage),

- increasing number of people and equipment,

- using equipment more efficient than actually required.

- technological universalism (flexibility),

- organisational changes that extend the available time of work and which allow a reduction of the required volume of resources,

- adoption of integrated management systems (WMS) to eliminate out-of-system activities,

- adoption of motivation programmes of the employees. 
A review of the following aspects allows the presumption that planning of a warehouse facility requires taking into account redundancy of the following nature:

- Functional (flexibility, universalism), i.e. possibilities of functional reconfiguring of the system to allow its adaptation to the nature of implemented logistic tasks.

- Technological (oversizing), i.e. an overcapacity in efficiency as compared to needs.

Redundancy always has to be confronted with the effectiveness of the warehouse and whole supply chain. Oversizing to exceed actual needs causes a high unit cost of tasks, while universalism may cause a drop in competitiveness. The adequacy of that cost arises from market conditions.

Organisational methods aimed at increasing the dependability of a warehouse are based on the following:

- rational allotment of resources for needs of warehouse tasks in time,

- determination of available time for task implementation during the day,

- selection of universal devices which may be moved between tasks,

- adoption of methods directing the flow of materials to and from the given location to reduce the work intensity of the process, in the function of costs of task implementation and availability of resources.

The dependability of the warehouse may be periodically enhanced by the adoption of organisational means aimed at increasing the utilisation rate of the working time (e.g. by motivating) or permanently by application of warehouse management systems. Temporary factors that enhance efficiency, and consequently improve the overall dependability of the warehouse in the supply chain include the possibility of extending the daily working time. Long-term increase in performance by extending the daily working time requires employing additional people.

Functional redundancy is also contained in schedule of warehouse process that describes work pile-ups. Planning the process in a way that increases the available time of task implementation concurrently maintaining the same state of resources would allow enhancing the system potential [13].

Both technological and functional redundancy are indispensable for proper realization of warehouse processes. Certain aspects of technological and functional redundancy may be taken into consideration in the project phase, as was outlined below.

\section{Synthetic warehouse dependability measure}

Warehouse dependability can be related to the basic features of properly realized logistics service defined by 7R rule [19], which means transforming entering material flows (from suppliers) into materials for clients according to orders, within agreed time, with adequate quality and costs. Quality of warehouse services is sufficient, and consequently its dependability is satisfactory, when number and structure of qualitative errors is admissible by client, services are provided on time and warehouse is capable of handling predictable and non-predictable pile-ups in material flows. Then, it is possible to determine overall dependability measure OTIFEF (On-Time, In-Full, Error-Free) of warehouse on the base of warehousing operations history $[14,19]$. OTIFEF measure is basically the ratio of tasks (services) completed in a way fully satisfying customers (model) to the number of all ordered tasks.

Boundary conditions of warehouse operation are determined by structure of deliveries on one side and structure of shipments resulting from customer orders on the other. Customer satisfaction must go hand in hand with correct servicing of suppliers. Thus, OTIFE-
$F_{\text {in }}$ describes quality of servicing suppliers (feeding warehouse) and $O T I F E F_{\text {out }}$ describes quality of shipments (emptying warehouse) [14]. Both measures are defined by a set of parameters determining quality of work, but generally can be composed as follows:

$$
\forall m \in \boldsymbol{M} \operatorname{OTIFEF}_{\text {in }}(m)=P_{\text {OTin }}(m) \cdot P_{\text {IFin }}(m) \cdot P_{\text {EFin }}(m)
$$

where:

$P_{\text {OTin }}(m)$ - probability of handling all (daily) supplies on-time in $m$-th warehouse,

$P_{\text {IFin }}(m)$ - probability of handling all (daily) supplies in-full in $m$-th warehouse,

$P_{E F i n}(m)$ - probability of handling all (daily) supplies with no errors in $m$-th warehouse.

A similar function is formulated for shipments:

$$
\forall m \in M \text { OTIFEF } F_{\text {out }}(m)=P_{\text {OTout }}(m) \cdot P_{\text {IFout }}(m) \cdot P_{\text {EFout }}(m)
$$

where:

$P_{\text {OTout }}(m)$ - probability of handling all (daily) shipments on-time in $m$-th warehouse,

$P_{\text {IFout }}(m)$ - probability of handling all (daily) shipments in-full in $m$-th warehouse,

$P_{\text {EFout }}(m)$ - probability of handling all (daily) shipments with no errors in $m$-th warehouse.

For the purpose of research, probabilities are considered as independent. This can result in underestimation of warehouse dependability expressed by formulas (1) or (2), but is acceptable when functions are used for comparing technical and organizational variants.

Probabilities of handling all shipments and supplies on-time $P_{O T}$ are directly dependent on technical potential od warehouse. Probabilities of quality error $P_{E F}$ are related to human factor and random events. Probabilities $P_{I F}$ of servicing daily supplies and shipments infull are related to the availability of free storage place and ordered materials on hand, which are dependent on inventory planning strategies and indirectly on storage capacity.

\section{Reliable material flow volumes vs punctuality}

The fundamental step of designing warehouse is determining reliable (nominal) material flow volumes on entrance (supplies) and on exit (shipments). Reliable material flows constitute the base for counting number of handling equipment, workers and spaces. Installed technical potential must be able to handle all daily supplies and shipments and random pile-ups in material flow volumes.

Volumes of materials entering the warehouse and leaving it can be described by the relevant distribution (example for supplies in Figure 2).

Daily material flow volumes on entrance are described by random variable $\left\{\lambda_{i n}(m), p\left(\lambda_{i n}(m)\right)\right\}$ and on exit (shipments) by $\left\{\lambda_{\text {out }}(m), p\left(\lambda_{\text {out }}(m)\right)\right\}$. Flow volumes are expressed by number of handled unified units. Average daily flow volumes are then set as expected values:

$$
\begin{gathered}
\forall m \in \boldsymbol{M} \quad \lambda_{\text {in }}^{\text {av }}(m)=E\left(\lambda_{\text {in }}(m)\right) \text { and } \\
\forall m \in \boldsymbol{M} \quad \lambda_{\text {out }}^{\text {av }}(m)=E\left(\lambda_{\text {out }}(m)\right)
\end{gathered}
$$




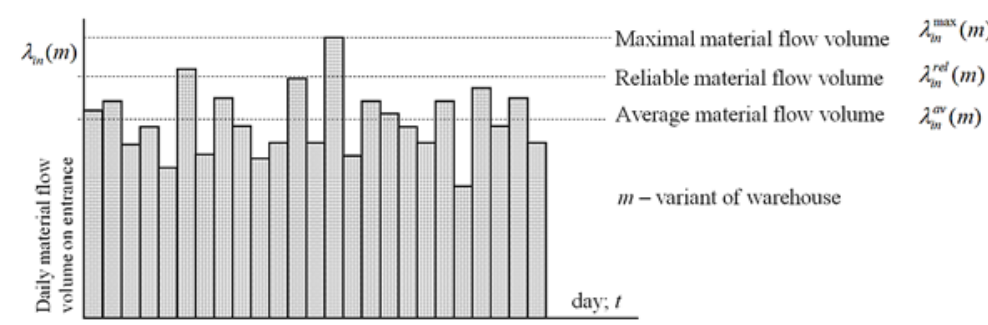

Fig. 2. Distribution of material flow volume on warehouse entrance (supplies). Source: own work

Reliable flow volumes are the expected volumes that must be serviced on-time, even under statistically expected equipment breakdowns and workers' unavailability (necessary redundancy). Finding reliable flow volumes is difficult and depends on type of warehouse, supply chain organization and serviced business.

Random variables $\left\{\lambda_{\text {in }}(m), p\left(\lambda_{\text {in }}(m)\right)\right\}$ and $\left\{\lambda_{\text {out }}(m), p\left(\lambda_{\text {out }}(m)\right)\right\}$ are characterized by coefficients of variation $V$ :

$$
V_{\text {in }}(m)=\frac{\sigma_{\text {in }}(m)}{\mu_{\text {in }}(m)} \text { and } V_{\text {out }}(m)=\frac{\sigma_{\text {out }}(m)}{\mu_{\text {out }}(m)}
$$

where $\mu$ is the mean and $\sigma$ is the standard deviation.

Coefficients of variation $V$ are different for different material flow strategies in supply chain, but observations and analyses revealed reference values (Table 1).

Table 1. Exemplary variation coefficients of material flow volumes in warehouse facility.

\begin{tabular}{||l|c|c|c||}
\hline \multicolumn{1}{|c|}{ Type of warehouse } & Minimal $\boldsymbol{V}$ & $\ldots$ & Maximal $\boldsymbol{V}$ \\
\hline Industry (production) warehouse entries (supplies) & 0,03 & 0,07 & 0,12 \\
\hline Industry (production) warehouse exit (shipments) & 0,02 & 0,05 & 0,1 \\
\hline Distribution (retail) warehouse entries (supplies) & 0,2 & 0,35 & 0,65 \\
\hline Distribution (retail) warehouse exit (shipments) & 0,35 & 0,45 & 1,12 \\
\hline
\end{tabular}

Source: own research.

The variation coefficient $V<0,1$ is considered as irrelevant, which is reflected in the way of setting reliable material flow volumes on entrance and on exit:

$$
\forall m \in M \text { if }\left\{\begin{array}{cc}
V_{\text {in }}(m) \leq k 1_{\text {in }}(m) \rightarrow & \lambda_{\text {in }}^{\text {rel }}(m)=\lambda_{\text {in }}^{\text {max }}=\max \left\{\lambda_{\text {in }}(m)\right\} \\
V_{\text {in }}(m)>k 1_{\text {in }}(m) \rightarrow & \lambda_{\text {in }}^{\text {rel }}(m)=E\left(\lambda_{\text {in }}(m)\right)+k 2_{\text {in }} \sqrt{E\left(\left(\lambda_{\text {in }}(m)\right)^{2}\right)-E\left(\lambda_{\text {in }}(m)\right)^{2}}
\end{array}\right.
$$

and

$\forall m \in M$ if $\left\{\begin{array}{cc}V_{\text {out }}(m) \leq k 1_{\text {out }}(m) \rightarrow & \lambda_{\text {out }}^{\text {rel }}(m)=\lambda_{\text {out }}^{\max }=\max \left\{\lambda_{\text {out }}(m)\right\} \\ V_{\text {out }}(m)>k 1_{\text {out }}(m) \rightarrow & \lambda_{\text {out }}^{\text {rel }}(m)=E\left(\lambda_{\text {out }}(m)\right)+k 2_{\text {out }} \sqrt{E\left(\left(\lambda_{\text {out }}(m)\right)^{2}\right)-E\left(\lambda_{\text {out }}(m)\right)^{2}}\end{array}\right.$

where:

$k 1_{\text {in/out }}(m)$ - variation coefficient determining irrelevancy for particular decision situation,

$k 2_{\text {in/out }}(m)-$ index representing required warehouse service level.

Low $V$ means that material flow is not disturbed by random pileups and is non-changeable so reliable flow volume is equal to maximal flow volume. This situation is characteristic for warehouses handling high volumes of unified, non-seasonal products (like feeding pro- duction or cross-docking). High variation coefficient $V$ means that warehouse experiences high pile-ups in material flows. In many cases pile-ups appear rarely and don't justify installing redundant handling potential. These pile-ups excessing reliable flow volumes must be serviced by extra potential of three types, which may be combined (Table 2).

Table 2. The possibilities of serving material flow pile-ups exceeding reliable material flows.

\begin{tabular}{|c|l||}
\hline Event & \multicolumn{1}{|c|}{ Description } \\
\hline A & $\begin{array}{l}\text { universal equipment and workers can be moved from } \\
\text { other tasks and places in warehouse to handle high } \\
\text { pile-ups on entrance or on exit }\end{array}$ \\
\hline B & $\begin{array}{l}\text { daily work time can be extended (additional FTE) } \\
\text { or short-term improvement of work time utilization } \\
\text { through motivation methods can be used }\end{array}$ \\
\hline C & $\begin{array}{l}\text { extra equipment, storage space and human resources } \\
\text { can be gained from outside (renting equipment and } \\
\text { space, hiring temporary workers) }\end{array}$ \\
\hline \hline
\end{tabular}

Source: own research.

Hence values of key importance for warehouse designing are the pile-up coefficients:

$$
\forall m \in \boldsymbol{M} \varphi_{\text {in }}(m)=\frac{\lambda_{\text {in }}^{r e l}(m)}{\lambda_{\text {in }}^{a v}(m)} \text { and }
$$

$$
\forall m \in M \quad \varphi_{\text {out }}(m)=\frac{\lambda_{\text {olt }}^{\text {rel }}(m)}{\lambda_{\text {out }}^{\text {av }}(m)}
$$

Therefore, warehouse facility can be described by important dependability characteristics:

$$
\forall m \in \boldsymbol{M} P\left(\frac{\lambda_{\text {in }}(m)}{\lambda_{\text {in }}^{a v}(m)} \leq \varphi_{\text {in }}(m)\right)=\alpha_{\text {in }}(m) \text { and }
$$

$$
\forall m \in \boldsymbol{M} P\left(\frac{\lambda_{\text {out }}(m)}{\lambda_{\text {out }}^{\text {av }}(m)} \leq \varphi_{\text {out }}(m)\right)=\alpha_{\text {out }}(m)
$$

It was assumed that $\alpha_{i n}(m)=\alpha_{\text {out }}(m) \geq 0,96$ is a typical value, but it depends on the analysed case. Number of workers and equipment and storage capacities are set to meet determined material flow volumes. Assuming certain simplifications and invariability of technology, it can be stated that these numbers are proportional to the daily flow volume.

Concluding formulas (1), (2) and (6), (7) warehouse dependability in terms of punctuality can be considered in aspect of technical redundancy in two ways:

- event $\mathrm{H}_{1 \text { in }}$ when $\lambda_{\text {in }}(m) \leq \lambda_{\text {in }}^{\text {rel }}(m)$ - flow volumes on entrance are below the limit, so can be handled on-time in $100 \%$.

- event $\mathrm{H}_{2 i n}$ when $\lambda_{\text {in }}(m)>\lambda_{\text {in }}^{\text {rel }}(m)$ - flow volumes on entrance are over the limit, so can't be handled on-time in $100 \%$.

- event $\mathrm{H}_{1 \text { out }}$ when $\lambda_{\text {out }}(m) \leq \lambda_{\text {out }}^{\text {rel }}(m)$ - flow volumes on exit are below the limit, so can be handled on-time in $100 \%$. 
Table 3. Structure of errors in order-picking process in company X.

\begin{tabular}{||c|c|c|c|c|c|c|c|c|c|c||}
\hline Parameter & Jan & Feb & Mar & Apr & May & Jun & Jul & Aug & Sep & Oct \\
\hline No of picked lines & 31360 & 18722 & 12095 & 16802 & 11991 & 9988 & 11489 & 7119 & 7939 & 11425 \\
\hline Number of errors & 54 & 26 & 48 & 43 & 23 & 47 & 13 & 38 & 26 & 30 \\
\hline - quality errors & 28 & 16 & 32 & 29 & 16 & 32 & 11 & 25 & 15 & 20 \\
\hline - quantitative errors & 26 & 10 & 16 & 14 & 7 & 15 & 2 & 13 & 11 & 10 \\
\hline
\end{tabular}

Source: own research.

- event $\mathrm{H}_{2 \text { out }}$ when $\lambda_{\text {out }}(m)>\lambda_{\text {out }}^{\text {rel }}(m)$ - flow volumes on exit are over the limit, so can't be handled on-time in $100 \%$.

If $\lambda_{i n}^{r e l}(m)=\lambda_{i n}^{\max }(m)$ for $m$-th warehouse (formula (6)), then:

$$
P_{\text {OTin }}(m)=P\left(\mathrm{H}_{1 \text { in }}\right) \approx 1,
$$

and similarly if $\lambda_{\text {out }}^{\text {rel }}(m)=\lambda_{\text {out }}^{\max }(m)$ for $m$-th warehouse (formula (7)), then:

$$
P_{\text {OTout }}(m)=P\left(\mathrm{H}_{1 \text { out }}\right) \approx 1
$$

If $\lambda_{i n}^{\text {rel }}(m)<\lambda_{i n}^{\max }(m)$ for $m$-th warehouse (formula (6)), then: ways of coping with pile-ups presented in Table 2 are applied:

$$
\begin{aligned}
P_{\text {OTin }} & =P\left(\mathrm{H}_{2 \text { in }} / \mathrm{A}\right) \cdot P(\mathrm{~A})+P\left(\mathrm{H}_{2 i n} / \mathrm{B}\right) \cdot P(\mathrm{~B})+P\left(\mathrm{H}_{2 i n} / \mathrm{C}\right) \cdot P(\mathrm{C})+ \\
& +P\left(\mathrm{H}_{2 i n} / \mathrm{A} \cap \mathrm{B} \cap \mathrm{C}\right) \cdot P(\mathrm{~A} \cap \mathrm{B} \cap \mathrm{C})+P\left(\mathrm{H}_{2 i n} / \mathrm{A} \cap \mathrm{B}\right) \cdot P(\mathrm{~A} \cap \mathrm{B})+ \\
& +P\left(\mathrm{H}_{2 i n} / \mathrm{A} \cap \mathrm{C}\right) \cdot P(\mathrm{~A} \cap \mathrm{C})+P\left(\mathrm{H}_{2 \text { in }} / \mathrm{B} \cap \mathrm{C}\right) \cdot P(\mathrm{~B} \cap \mathrm{C})
\end{aligned}
$$

where $P(\mathrm{~A}), P(\mathrm{~B})$ and $P(\mathrm{C})$ are appropriate probabilities describing availability of particular solutions in analyzed warehouse at the time of pile-ups.

Similarly, if $\lambda_{\text {out }}^{\text {rel }}(m)<\lambda_{\text {out }}^{\max }(m)$ for $m$-th variant of the warehouse (formula (7)), then:

$$
\begin{aligned}
P_{\text {OTout }} & =P\left(\mathrm{H}_{2 \text { out }} / \mathrm{A}\right) \cdot P(\mathrm{~A})+P\left(\mathrm{H}_{2 \text { out }} / \mathrm{B}\right) \cdot P(\mathrm{~B})+P\left(\mathrm{H}_{2 \text { out }} / \mathrm{C}\right) \cdot P(\mathrm{C})+ \\
& +P\left(\mathrm{H}_{2 \text { out }} / \mathrm{A} \cap \mathrm{B} \wedge \mathrm{C}\right) \cdot P(\mathrm{~A} \cap \mathrm{B} \cap \mathrm{C})+P\left(\mathrm{H}_{2 \text { out }} / \mathrm{A} \cap \mathrm{B}\right) \cdot P(\mathrm{~A} \wedge \mathrm{B})+ \\
& +P\left(\mathrm{H}_{2 \text { out }} / \mathrm{A} \cap \mathrm{C}\right) \cdot P(\mathrm{~A} \cap \mathrm{C})+P\left(\mathrm{H}_{2 \text { out }} / \mathrm{B} \cap \mathrm{C}\right) \cdot P(\mathrm{~B} \cap \mathrm{C})
\end{aligned}
$$

The high capacity of pile-ups handling requires maintaining a considerable technological potential in readiness - redundancy. The possibility of handling smaller pile-ups generate lower costs, yet it would also limit the readiness of the warehouse to provide services. Technological redundancy resulting from handleable pile-ups in material flow is reflected in organizational and technical indicators of warehouse system.

\section{Structure of qualitative errors and availability of materials}

As described in section 4. synthetic measure of warehouse dependability OTIFEF is based on three components. The first component (On-time) is discussed in section 5. The other two are difficult to be measured and require data mining.

Structure of qualitative errors made by the employees (component Error-free) can be estimated only through analysis of histori- cal data of warehouse operation or using methods like FMECA (see [33]). Analysis of historical data allows to determine the probability distributions of qualitative errors under specific technological and organizational configuration of warehouse and known workload. Of course, there are technologies and solutions that contribute to minimizing the number of errors - especially automated technologies and strict control of the process by the warehouse information system like WMS. Unfortunately, the effect of the implementation of such technologies can be determined only on the basis of analysis of their work.

An analysis of the structure of errors in order picking process in real warehouse was performed to illustrate the problem. The analysis covered a period of 10 months, during which 138930 lines of orders was realized (Table 3 ).

The analysis has revealed that probability distribution of correct execution of the orders can be approximated by Weibull distribution. Estimated expected probability of error-free implementation of single order-line in terms of quality is 0.9972656 and in terms of quantity is 0.9984898 . The probability of faultless execution of order-line is then 0.9957417 . The probabilities set in that way can be used to determine the $O T I F E F_{\text {out }}$ index. It must be noted that these data do not include errors that were identified before sending materials to customers.

The last component of the measure - In-full is a function of the availability of space for storage units incoming to the warehouse and on-hand availability of ordered materials to be released. It results from the supply and distribution planning mechanisms, product features and warehouse storage area capacity. In addition, the products in most types of businesses can be divided into fast and slow-moving. In typical situations, fast moving materials are likely available immediately (make-to-stock), while the slow-moving products may not be available at the time of placing an order (make-to order). It is thus possible to determine the probabilities of execution of orders "in-full".

\section{Selected technical and organizational indicators of warehouse system redundancy}

\subsection{Elements of dependability structure of warehousing system}

Basic criteria for assessing the quality of a warehouse as an element of the supply chain should comprise technical measures (productivity, performance), economic measures (costs and investment expenditures) and qualitative measures (number and structure of errors). These measures are useful for determining dependability in terms of redundancy. All elements of the supply chain must meet separate expectations as to efficiency. This indicates that elements within the chain may be perceived as the dependability system of the entire series. Lack of reliability of one or more elements is transposed on the lack of reliability of the entire supply chain. And vice versa, dependability of particular elements of the supply chain causes that it may meet expectations related to efficiency on all markets in its surroundings.

Hence, if we assume that the analysed supply chain is of a serial structure and we know:

- set of elements of supply chain $\boldsymbol{V}=\{v: v=\overline{1, V}\}$, 
- set of connections between elements

$\boldsymbol{L}=\left\{\left(v, v^{\prime}\right): v, v^{\prime} \in \boldsymbol{V} \wedge\left(v, v^{\prime}\right) \in \boldsymbol{V} \times \boldsymbol{V} \wedge v \neq v^{\prime}\right\}$

- dependability indicator of the $v$-th elements of supply chain: $n l(v)$;

- dependability indicator of connection between links $\left(v, v^{\prime}\right)$ of supply chain: $n l\left(v, v^{\prime}\right)$,

dependability in the structural sense for the entire chain may be determined as following:

$$
W N S=\prod_{\left(v, v^{\prime}\right) \in \boldsymbol{L}} n l\left(v, v^{\prime}\right) \cdot \prod_{v \in \boldsymbol{V}} n v(v)
$$

Furthermore, taking into account the routes implemented in supply chains, assuming that the following data have been determined:

- set of sources of material flow in supply chain: $\boldsymbol{A}$,

- set of destinations of material flow in supply chain: $\boldsymbol{B}$,

- set of numbers of routes which may join sources with end nodes: $\boldsymbol{E}(a, b), a \in \boldsymbol{A}, b \in \boldsymbol{B}$

- set of numbers of nodes for all routes: $\boldsymbol{E} \boldsymbol{W}(a, b, e), a \in \boldsymbol{A}$, $b \in \boldsymbol{B}, e \in \boldsymbol{E}(a, b)$

- set of edges determining $e$-th flow itinerary in supply chain in relation $(a, b): \boldsymbol{E} \boldsymbol{L}(a, b, e), a \in \boldsymbol{A}, b \in \boldsymbol{B}, e \in \boldsymbol{E}(a, b)$.

dependability of the supply chain in the sense of transport and warehouse routes may be defined in the following way:

$W N C=\prod_{a \in \boldsymbol{A}} \prod_{b \in \boldsymbol{B}}\left[\sum_{e \in \boldsymbol{E}(l d, a, b)}\left(\prod_{\left(v, v^{\prime}\right) \in \boldsymbol{E} \boldsymbol{L}(a, b, e)} n l\left(v, v^{\prime}\right) \cdot \prod_{v \in \boldsymbol{E} \boldsymbol{W}(a, b, e)} n v(v)\right)\right]$

Ascribing of highly reliable resources or excessive number of resources to the realization of particular routes in supply chain increases the operability of the entire chain.

\subsection{Selected technical and organisational measures of redundancy of warehouse system in aspect of task implementation dependability}

It was assumed that given supply chain uses $M$ warehouses. Set of numbers of warehouses is denoted as $\boldsymbol{M}=\{m: m=\overline{1, M}\}$. Each warehouse uses a set of resources (equipment and workers). A single type of resource in $m$-th warehouse is marked as $r$, so the set $\boldsymbol{R}(m)$ of resources is described as following:

$$
\forall m \in \boldsymbol{M} \quad \boldsymbol{R}(m)=\{r: r=1,2, \ldots, R(m)\} .
$$

It was assumed that the warehouse process consists of sequentially numbered transformations of material flows $i, j \in \boldsymbol{I}(m)$ implemented by resources $r \in \boldsymbol{R}(m)$. If $\alpha(r, m, i)=1$ then $r$-th type of resource implements $i$-th task in $m$-th warehouse. The daily work-load of the $r$-th type resource is the sum of products of the number of transport operations under $i$-th tasks $\lambda(m, i)$ and the duration of a single reiteration $t(r, m, i)$ by $r$-th resource:

$$
\forall m \in \boldsymbol{M} \forall r \in \boldsymbol{R}(m) \quad \Psi(r, m)=\sum_{i \in \boldsymbol{I}(m)} \alpha(r, m, i) \cdot \lambda(m, i) \cdot t(r, m, i)
$$

where: $\forall m \in \boldsymbol{M} \forall i \in \boldsymbol{I}(m) \quad \lambda(m, i)=\lambda^{a v}(m, i) \cdot \varphi_{i n}(m)$ or $\lambda(m, i)$ $=\lambda^{a v}(m, i) \cdot \varphi_{\text {out }}(m)$

depending on whether $i$-th task is for handling supplies (in) or shipments (out).
Each type of resource has a specified cost of hourly operation $k(r, m)$. Balancing the workload $\Psi(r, m)$ with the cost of operation allows obtaining standardised workload, which may be added for all types of equipment:

$$
\forall m \in \boldsymbol{M} \widetilde{\Psi}(m)=\sum_{u \in \boldsymbol{R}(m)} \frac{\Psi(r, m) \cdot k(r, m)}{\min \{k(r, m): r \in \boldsymbol{R}(m)\}}
$$

The number $n(r, m)$ of $r$-th resources is known. Standardised number of resources may be determined, which is to define the technological redundancy of the warehouse as compared to other variants of the system:

$$
\forall m \in \boldsymbol{M} \bar{n}(m)=\sum_{r \in \boldsymbol{R}(m)} \frac{\alpha(r, m, i) n(r, m) k(r, m)}{\min \{k(r, m): r \in \boldsymbol{R}(m)\}}
$$

Each task has an assigned available implementation time $t d(i, m)$ arising from the daily warehouse operation schedule. The tasks may be implemented concurrently, which as a result leads to overlapping of tasks in certain periods and work piling up.

Indicator of available operating time utilization

Consequently, the technological redundancy of a warehouse system that determines its dependability may be expressed by the indicator of available operating time utilization of technical resources of the $r$-th type:

$$
\forall m \in \boldsymbol{M} \quad \theta(r, m)=\frac{\sum_{i \in \boldsymbol{I}(m)} \Psi(r, m)}{n(r, m) \varphi(r, m) t_{d o b}(m)}
$$

where:

$t_{d o b}(m)$ - daily operating time of the $m$-th warehouse,

$\varphi(r, m)$ - operating time utilisation by $r$-th resources in $m$-th warehouse.

This indicator is a quotient of the work-load and daily operating time appointed to the resources of the given type. Controlling the daily operating time for task implementation is a basic organisational tool oriented at increasing the efficiency of the warehouse and used to handle non-standard pile-ups in material flow.

\section{Cost-related organisational index}

The potential technical redundancy of the warehouse system may also be expressed in cost categories, among others by the cost-based organisational indicator for assessing the utilisation level of installed devices:

$$
\forall m \in \boldsymbol{M} \quad \theta_{o z}^{K}(m)=\frac{K^{R o}(m)}{K_{T}^{R}(m)+K_{S}^{R}(m)+K_{L}^{R}(m)}
$$

where:

$K^{R o}(m)$ - annual operating costs (direct cost of labour and equipment usage) [PLN/year],

$K_{T}^{R}(m)$ - total annual maintenance costs (all costs, including depreciation) [PLN/year],

$K_{S}^{R}(m)$ - total annual maintenance costs of control systems [PLN/ year],

$K^{R}(m)$ - total annual labour costs [PLN/year].

The optimum value of this indicator -1 , means that all resources are used in $100 \%$ during the working day. Lower values point to the 
existence of a technological potential, which may be initiated by taking up appropriate organisational means. In most cases this potential is not used due to the defined allotment of resources and work organisation contributing to work pile-ups that involve all resources, which are not used in the remaining time.

\section{Organisational index expressed by standardised work intensity}

The organisational index expressed by standardised work intensity of process implementation may be described in the following way:

$\forall m \in \boldsymbol{M} \theta_{o z}^{\widetilde{\Psi}}(m)=\sum_{r \in \boldsymbol{R}(m)} \frac{\Psi(r, m) \cdot k(r, m)}{\sum_{r^{\prime} \in \boldsymbol{R}(m)} k\left(r^{\prime}, m\right) t_{d o b}(m) \max _{\tau \in \boldsymbol{T}}\{\Psi(r, m, \tau)\}}$

where: $\max _{\tau \in \boldsymbol{T}}\{\Psi(r, m, \tau)\}$ is maximal temporary work intensity for the $r$-th type of resource arising from work pile-ups at $\tau$-th moment during a 24-hour period $[\mathrm{m} . \mathrm{h} / \mathrm{h}]$,

The maximum temporary work intensity of the process $\max _{\tau \in \boldsymbol{T}}\{\Psi(r, m, \tau)\}$ with view to operation of $r$-type resources is understood as a maximum sum of work intensity of successive $i$-th tasks implemented in a parallel way falling for the $\tau$-th time interval. The distribution of task implementation during each 24-hour period arises from the schedule (organisation).

\section{Example of determining selected redundancy meas- ures for dependability assessment}

The research was carried out for a warehouse executing processes composed of 14 tasks. Potential pile-ups in deliveries and shipments are set by the pile-up coefficients. The installed potential was analysed with view of effectiveness and efficiency for pile-up coefficients on entry $\varphi_{\text {in }}$ and at exit $\varphi_{\text {out }}$ as $1.1 ; 1.3$ and 1.5 respectively. The warehouse has at its disposal resources presented in Table 4.

The warehouse is working one shift 290 days a year. There are no seasonal changes in material flows. The average size of daily reloading operations on entry: 300 pallet units. The average number of release operations: 455 (including consolidated and homogenous units). The workload of successive tasks of the process arise from the technology and geometry of the building. The floor area and the storage capacity remain unchanged. An analysis was performed of the performance and warehouse costs for he defined schedule and without it (allotting the entire daily working time for tasks) to determine the potential organisational reserve.

Results of efficiency of scheduled warehouse operation are presented in Table 5. Standardised work intensity of the process which

Table 4. Listing of types of devices ( $u$ ) and categories of human labour (c) in the warehouse.

\begin{tabular}{|c|c|c|c|c|}
\hline Type & Description & Q-ty & $\begin{array}{l}\text { Cost of an hour of work [PLN/h] } \\
\text { - net as regards employees }\end{array}$ & $\begin{array}{c}\text { Utilisation degree of working } \\
\text { time }\end{array}$ \\
\hline$u 1$ & Powered lifting pallet truck & 3 & 4.00 & 0.8 \\
\hline$u 2$ & Front lifting pallet truck & 14 & 7.00 & 0.9 \\
\hline u3 & Horizontal order picking trolley & 9 & 9.00 & 0.9 \\
\hline$u 4$ & High reach truck & 8 & 12.00 & 0.9 \\
\hline$c 1$ & Operator of $u 1, u 2+$ manual work & \multirow{3}{*}{ var. } & 13.00 & 0.8 \\
\hline$c 2$ & Employee for picking and control & & 16.00 & 0.8 \\
\hline$c 3$ & Operator of $u 2$ and $u 3$ & & 20.00 & 0.8 \\
\hline
\end{tabular}

Table 5. Technical parameters of warehouse operation - with schedule.

\begin{tabular}{|c|c|c|c|c|c|c|c|c|c|}
\hline \multirow{2}{*}{ Parameter } & \multicolumn{9}{|c|}{ Variant } \\
\hline & 1 & 2 & 3 & 4 & 5 & 6 & 7 & 8 & 9 \\
\hline$\varphi_{\text {in }}$ & 1.5 & 1.5 & 1.5 & 1.3 & 1.3 & 1.3 & 1.1 & 1.1 & 1.1 \\
\hline$\varphi_{\text {out }}$ & 1.5 & 1.3 & 1.1 & 1.5 & 1.3 & 1.1 & 1.5 & 1.3 & 1.1 \\
\hline \multicolumn{10}{|c|}{ Maximum intensity of standardised work intensity } \\
\hline with view to operation of devices [m.h] & 57.50 & 52.48 & 47.46 & 54.89 & 49.87 & 44.84 & 52.23 & 47.20 & 42.18 \\
\hline with view to labour of employees [m.h] & 41.95 & 38.32 & 34.69 & 40.01 & 36.39 & 32.76 & 38.03 & 34.40 & 30.78 \\
\hline \multicolumn{10}{|c|}{ Standardised work intensity } \\
\hline with view to operation of devices [m.h] & 324.88 & 296.67 & 268.46 & 309.94 & 281.73 & 253.52 & 294.74 & 266.53 & 238.32 \\
\hline with view to labour of employees [m.h] & 233.55 & 213.38 & 193.21 & 222.72 & 202.55 & 182.38 & 211.67 & 191.50 & 171.33 \\
\hline \multicolumn{10}{|c|}{ Organisational indicator \#1 - effectiveness of utilisation of installed potential } \\
\hline with view to operation of devices: & 0.706 & 0.707 & 0.707 & 0.706 & 0.706 & 0.707 & 0.705 & 0.706 & 0.706 \\
\hline with view to labour of employees: & 0.696 & 0.696 & 0.696 & 0.696 & 0.696 & 0.696 & 0.696 & 0.696 & 0.696 \\
\hline \multicolumn{10}{|c|}{ Organisational indicator \#2 - unutilised technological potential (standardised work intensity) } \\
\hline with view to operation of devices [m.h] & 135.15 & 163.36 & 191.57 & 150.09 & 178.30 & 206.52 & 165.29 & 193.50 & 221.71 \\
\hline with view to labour of employees [m.h] & 102.07 & 122.24 & 142.41 & 112.90 & 133.07 & 153.24 & 123.95 & 144.12 & 164.29 \\
\hline \multicolumn{10}{|c|}{ Organisational indicator \#2 - unutilised technological potential (standardised work intensity) } \\
\hline with view to operation of devices & $29.4 \%$ & $35.5 \%$ & $41.6 \%$ & $32.6 \%$ & $38.8 \%$ & $44.9 \%$ & $35.9 \%$ & $42.1 \%$ & $48.2 \%$ \\
\hline with view to labour of employees & $30.4 \%$ & $36.4 \%$ & $42.4 \%$ & $33.6 \%$ & $39.6 \%$ & $45.7 \%$ & $36.9 \%$ & $42.9 \%$ & $49.0 \%$ \\
\hline
\end{tabular}




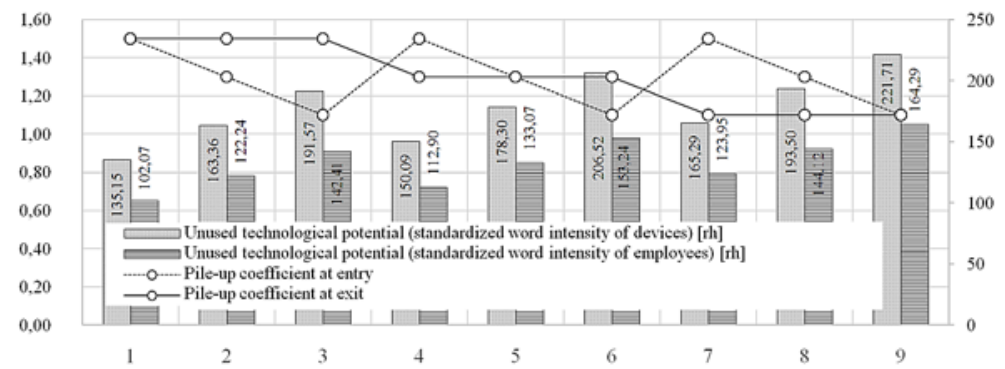

Fig. 3. Unused technological potential - with schedule expresses the general volume of work to be executed in relation to work costs was used for assessment of the technological overcapacity of the warehouse. Unused technological potential in variant 1 (the highest pile-ups at level $\alpha$ which may be handled) arises from the structure of the work schedule, in which tasks may only be implemented in certain sections of the daily operation time.

The level of unused technical and functional potential (redundancy) was presented on Fig. 3.

Table 6 presents performance results of warehouse operation without schedule (all tasks are executed evenly throughout the entire daily working time - no pile-ups occur, resources are used in 100\%). Actual and standardised work intensity are the same as if a schedule is applied.

Fig. 4. presents the technological redundancy for the process without the schedule. In variant 1 standardised work intensity is distributed evenly within the entire daily working time, hence the lack $(0 \%)$ of technological and organisational overcapacity. In subsequent variants the technological redundancy arises from redundant resources, and no functional redundancy occurs.

Table 7 and Fig. 5. list costs of warehouses processes. Annual operating costs take into account all costs connected with the execution of warehouse processes and maintaining warehouse infrastructure. All other dependability and technical indicators have to refer to operating costs as the ultimate profitability index.

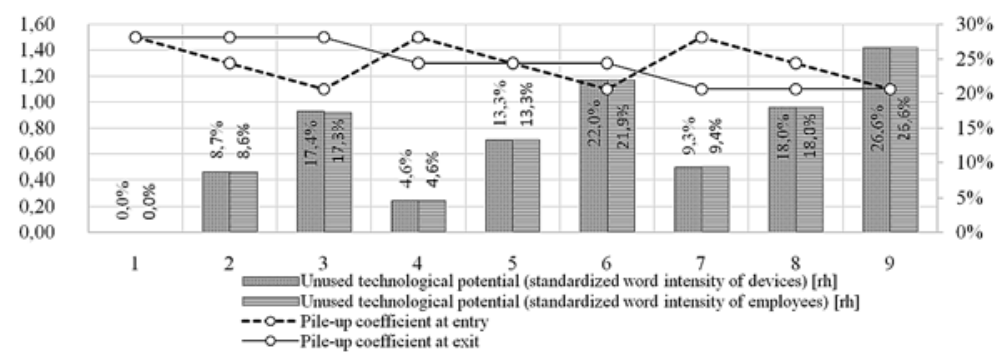

Fig. 4. Unused technological potential-with no schedule.
Fig. 6. presents costs of implementation of a single customer order depending on values of material pile-ups that may be handled. Also presented is the value of organisational indicator.

In case of lack of schedule and therefore daily pile-ups, investigated process may be carried out by the same resources (equipment) under pile-up coefficients on entry $\varphi_{i n}=2,98$ and at exit $\varphi_{\text {out }}=1,1$ and in the inverse situation under $\varphi_{\text {in }}=1,1$ and $\varphi_{\text {out }}=2,32$. This reserve (initial values of pile-up coefficients $\left.\varphi_{\text {in }}=\varphi_{\text {out }}=1,1\right)$ is significant. Naturally it cannot be fully used due to the technological limitations of the process, which will force the schedule, however, it indicates a potential functional redundancy possible to run under certain conditions.

Table 7. Listing of cost parameters for assessment of warehouse effectiveness - with schedule.

\begin{tabular}{|c|c|c|c|c|c|c|c|c|c|}
\hline \multirow{2}{*}{ Parameter } & \multicolumn{9}{|c|}{ Variant } \\
\hline & 1 & 2 & 3 & 4 & 5 & 6 & 7 & 8 & 9 \\
\hline$\varphi_{\text {in }}$ & 1.5 & 1.5 & 1.5 & 1.3 & 1.3 & 1.3 & 1.1 & 1.1 & 1.1 \\
\hline$\varphi_{\text {out }}$ & 1.5 & 1.3 & 1.1 & 1.5 & 1.3 & 1.1 & 1.5 & 1.3 & 1.1 \\
\hline \multicolumn{10}{|c|}{ Annual operational cost of work } \\
\hline of people [PLN million/year] & 2.780 & 2.476 & 2.300 & 2.589 & 2.425 & 2.171 & 2.538 & 2.234 & 2.058 \\
\hline of equipment [PLN million/year] & 0.420 & 0.384 & 0.347 & 0.401 & 0.365 & 0.328 & 0.382 & 0.345 & 0.308 \\
\hline \multicolumn{10}{|c|}{ Annual operating costs } \\
\hline of equipment [PLN million/year] & 4.928 & 4.891 & 4.854 & 4.908 & 4.872 & 4.835 & 4.889 & 4.852 & 4.816 \\
\hline of warehouse (total) [PLN million/year] & 8.360 & 8.019 & 7.806 & 8.149 & 7.949 & 7.658 & 8.079 & 7.738 & 7.525 \\
\hline Cost-related organisational indicator & 0.44 & 0.41 & 0.39 & 0.42 & 0.40 & 0.37 & 0.41 & 0.38 & 0.36 \\
\hline Effectiveness of solution [PLN/released unit] & 42.33 & 46.31 & 52.47 & 41.63 & 46.37 & 52.08 & 41.70 & 45.68 & 51.90 \\
\hline
\end{tabular}




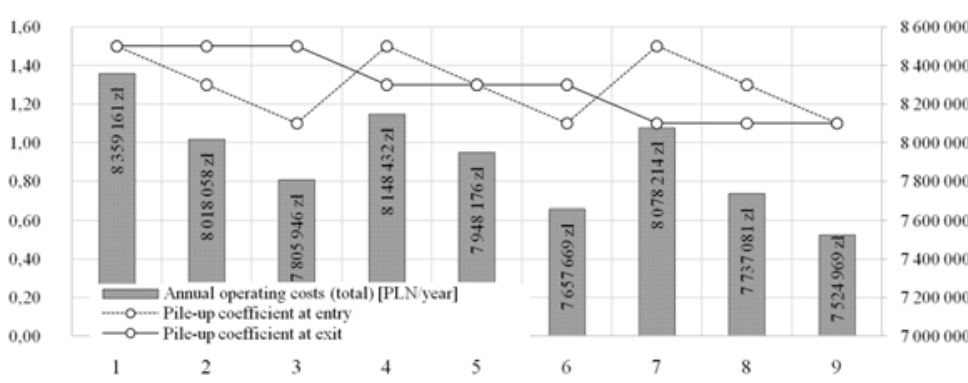

Fig. 5. Value of annual working cost for successive pile-up coefficients

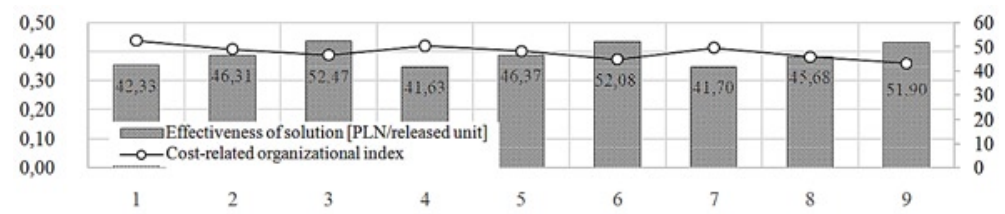

Fig. 6. Effectiveness of solutions in successive variants

\section{Conclusions}

Warehouses influence the quality of services in supply chain. In case of logistics systems quality can be identified with dependability issues, but their dependability cannot be defined and researched like in case technical systems. Dependability of warehouse determines its ability to ensure the continuity of core processes: the production and consumption. This ability can be expressed by a variety of characteristics.

Dependability in the implementation of warehouse processes may be enhanced not only by organisational means, but also technical modifications introducing necessary redundancy to reduce adverse events related to pile-ups in material flows and errors in process realization. Organisational tasks are oriented at increasing the utilisation level of the working time of resources and lowering pile-ups by spreading them over the longer time, while technical modifications are for increasing productivity.

Both actions are intended to increase the probability of correct execution of logistic services by the warehouse, and thus by the entire supply chain. This probability is defined by the OTIFEF index. The construction of OTIFEF index proposed in this paper is based on the probability of the three basic qualities of a well-executed logistics service. Therefore, it is universal and allows synthetic approach to issues of warehouse dependability referred to the quality of its work. It was pointed out that due to the complexity of operations in supply chains and randomness in the structure and size of material flows, these probabilities can be increased mainly by introducing rational redundancy at the designing stage.

Technical redundancy can be expressed by prosed technical and economic measures, which define frames of dependability structure of warehousing system. This structure can be a base of warehouses and supply chains dependability assessment, but the actual assessment can be made only by analysing historical data of processes realization.

Methods proposed in this paper are applicable. They were developed as elements of SIMMAG 3D project.

\section{Acknowledgement}

The research work supported by the National Center for Research and Development, in the frame of PBS 3 project "System for modeling and $3 D$ visualization of storage facilities" (SIMMAG3D).

\section{References}

1. Baghalian A, Rezapour S, Farahani R Z. Robust supply chain network design with service level against disruptions and demand uncertainties: A real-life case. European Journal of Operational Research 2013; 227(1): 199-215, https://doi.org/10.1016/j.ejor.2012.12.017.

2. Barnes E, Dai J, Deng S, Down D, Goh M, Lau H C, Sharafali M. On the Strategy of Shupply Hubs for Cost Reduction and Responsiveness. White Paper, The Logistics Institute - Asia Pacific. National University of Singapore, 2003.

3. Bramel J, Simchi-Levi D. The Logic of Logistics: Theory, Algorithms and Applications for Logistics Management. New York: SpringerVerlag, 1997, https://doi.org/10.1007/978-1-4684-9309-2.

4. Bukowski L. System of systems dependability - Theoretical models and applications examples. Reliability Engineering \& System Safety 2016; 151: 76-92, https://doi.org/10.1016/j.ress.2015.10.014. 
5. Bukowski L A. Zapewnienie ciągłości dostaw w zmiennym i niepewnym otoczeniu. Dąbrowa Górnicza: WSB, 2016.

6. Bukowski L, Feliks J. A unified model of systems dependability and process continuity for complex supply chains. Safety and Reliability: Methodology and Applications / Nowakowski T. [et al.] (ed.). CRC Press Taylor \& Francis Group, 2015: 2395-2403.

7. Chung S H, Chan H K, Chan F T S. A modified genetic algorithm for maximizing handling reliability and recyclability of distribution centers. Expert Systems with Applications 2013; 40(18): 7588-7595, https://doi.org/10.1016/j.eswa.2013.07.056.

8. Daganzo C F. Logistics Systems Analysis. New York: Springer Verlag, 1996, https://doi.org/10.1007/978-3-662-03196-4.

9. Grigoroudis E, Siskos Y. A survey of customer satisfaction barometers: Some results from the transportation-communications sector. European Journal of Operational Research 2004; 152: 334-353, https://doi.org/10.1016/S0377-2217(03)00028-6.

10. Haj Shirmohammadi A. Programming maintenance and repair. Technical management in industry, 8th edition. Esfahan: Ghazal Publishers, 2002.

11. Jacyna-Gołda I. Evaluation of operational reliability of the supply chain in terms of the control and management of logistics processes. Safety and Reliability: Methodology and Applications / Nowakowski T. [et al.] (ed.). CRC Press Taylor \& Francis Group, 2015: $549-558$.

12. Juściński S, Piekarski W. An analysis of a supply process of spare parts for agricultural tractors and machines based on logistic services outsourcing. Eksploatacja i Niezawodnosc - Maintenance and Reliability 2009; 2(42): 63-70.

13. Lewczuk K, Ambroziak T, Warehousing process scheduling in warehouse efficiency and reliability assessment. Proceedings of the 19th International Scientific Conference on Transport Means. Kaunas Univ Technol, Kaunas, 2015: 17-26.

14. Lewczuk K. Dependability issues in designing warehouse facilities and their functional areas. Journal of KONBiN 2016; 2(38): 201-228.

15. Neo H Y, Xie M, Tsui K L. Service quality analysis: case study of a 3PL company. International Journal of Logistics Systems and Management 2004; 1(1): 64-80, https://doi.org/10.1504/IJLSM.2004.005539.

16. Nowakowki T, Werbińska S. Zagadnienie oceny gotowości systemu logistycznego, Logistyka 2007; 5.

17. Nowakowski T. Analysis of possibilities of logistics systems reliability assessment. Safety and Reliability for managing risk 2006 ; 3 . Leiden: Taylor and Francis, 2006.

18. Nowakowski T. Models of uncertainty of operation and maintenance information. Zagadnienia Eksploatacji Maszyn 2000; $35(2)$ : $143-150$.

19. Nowakowski T. Niezawodność systemów logistycznych. Wrocław: OWPW, 2011.

20. Nowakowski T. Reliability model of combined transportation system. Probabilistic Safety Assessment and Management. Spitzer C, Schmocker U, Dang V N (ed.). London: Springer, 2004, https://doi.org/10.1007/978-0-85729-410-4_323.

21. Peng P, Snyder LV, Lim A, Liu Z L, Reliable logistics networks design with facility disruptions. Transportation Research Part B-Methodological 2011; 45(8): 1190-1211.

22. Quigley J, Walls L. Trading reliability targets within a supply chain using Shapley's value. Reliability Engineering \& System Safety 2007; 92(10): 1448-1457, https://doi.org/10.1016/j.ress.2006.09.019.

23. Rizzi A, Zamboni R. Efficiency improvement in manual warehouses through ERP systems implementation and redesign of the logistics processes. Logistics Information Management 1999; 12(5): 367 - 377, https://doi.org/10.1108/09576059910295805.

24. Rutkowski K. Logistyka dystrybucji. Warszawa: Wydawnictwa SGH, 2009.

25. Santoso T, Ahmed S, Goetschalck M, Shapiro A. A stochastic programming approach for supply chain network design under uncertainty. European Journal Of Operational Research 2005; 167(1): 96-115, https://doi.org/10.1016/j.ejor.2004.01.046.

26. Sawicki P. Wielokryterialna optymalizacja procesów w transporcie. Radom: Wydawnictwo ITE, 2013.

27. Seidler J A. Fundamental concepts of intelligent info system theory, Information Systems Architecture and Technology ISAT '94. Proceedings of 16th Scientific School. Wrocław: Oficyna Wydawnicza Politechniki Wrocławskiej, 1994.

28. Sohn S Y, Choi I S, Fuzzy QFD for supply chain management with reliability consideration. Reliability Engineering \& System Safety 2001: 72(3): 327-334,https://doi.org/10.1016/S0951-8320(01)00022-9.

29. Starowicz W. Jakość przewozów w miejskim transporcie zbiorowym. Kraków: Wydawnictwo Politechniki Krakowskiej, 2008.

30. Świderski A. Modelowanie oceny jakości usług transportowych. Prace Naukowe Politechniki Warszawskiej. Transport $2011 ; 81$.

31. Wasiak M. Simulation model of logistic system. Archives of Transport 2009; 21(3-4): 189-206.

32. Werbińska-Wojciechowska S. The availability model of logistic support system with time redundancy. Eksploatacja i Niezawodnosc Maintenance and Reliability 2007; 3(35): 23-29.

33. Werbińska-Wojciechowska S. Time resource problem in logistics systems dependability modelling. Eksploatacja i Niezawodnosc Maintenance and Reliability 2013; 15(4): 427-433.

34. Zamojski W. Teoria i technika niezawodności. Wrocław, 1976.

\section{Ilona JACYNA-GOŁDA}

Faculty of Production Engineering

Warsaw University of Technology

Narbutta 85, 02-524 Warsaw, Poland

\section{Konrad LEWCZUK}

Faculty of Transport

Warsaw University of Technology

Koszykowa 75, 00-662 Warsaw, Poland

E-mail: jacyna.golda@gmail.com,kle@wt.pw.edu.pl 